\title{
Investigation of courseware design of flue gas
}

\section{desulfurization of limestone-gypsum}

\author{
Wenfeng Hao* \\ Department of Energy and Chemical Engineering \\ College of Energy and Power Engineering \\ Shenyang Institute of Engineering \\ Shenyang, China \\ E-mail: haowenfeng@163.com
}

\begin{abstract}
Human-computer interaction and animation are introduced to Powerpoint teaching platform based on conventional teaching methods in order to improve teaching effects. Flue gas desulfurization of limestone-gypsum of thermal power plant is used to make teaching investigation as a sample in this paper because it is a mainstream technology in above $300 \mathrm{MW}$ coal-fired thermal power plants. Authorware erects a bridge between Powerpoint and industrial technology to provide some demonstrations such as system recognition with equipments and its function, system operation with different substance flow and test questions with certain knowledge training. Utilizing authorware tools a Powerpoint courseware embedded by an executed file of macromedia authorware 7 Runtime is formed, which has both numerous advantages of conventional courseware and substantial features of innovation. Under the help of the courseware, not only lectures can expound those equipments and running working conditions of the desulfurization system clearly, but also learners can have a more profound understanding for mass transfer, heat transfer, momentum transfer and chemical reaction in an industrial process related to environmental protection of thermal power plant fleetly, which brings a fruit with a win-win both professor and students.

Keywords: Engineering education; Courseware design; Power production; Flue gas desulfurization; Authorware and Powerpoint
\end{abstract}

\section{INTRODUCTION}

Sulphur oxidate is one of the main pollutants emitted by thermal power plant, which has a large proportion in the air pollutant. In order to solve the pollution problem of sulfur dioxide in power plant, a variety of control and emission reduction measures are applied in modern power plant [1-4]. In general, emission reduction methods of commonly used can be divided by wet flue gas desulfurization technology such as limestone gypsum method, ammonia method, seawater method [5-12]and dry flue gas desulfurization technology such as flue gas circulating fluidized bed, spraying calcium inside the furnace and tail humidifying activation and spray drying [13-16]. Facing complex and diverse flue gas desulfurization technology, a beginner wants to master them, who still need to spend a lot of energy and time. However, for the instructor if they want to solve this problem of the beginner's time-consuming and energyconsumption, it is necessary to improve and upgrade the courseware tool based on the traditional blackboard writing and a Powerpoint courseware of conventional type [17-20]. Authorware can remedy many shortcomings for general Powerpoint courseware because of its own advantages [21-23]. However, Authorware application is still few and has larger development spaces. Thus, a purpose of this work is to strengthen their visual effects for representations of static objects and dynamic pictures. Moreover, due to high desulfurization efficiency and wide application range, the limestone gypsum method has become the mainstream technology of the flue gas desulfurization above $300 \mathrm{MW}$ coal fired unit. If the technical process can be used to be investigated as a teaching courseware demonstration sample of flue gas desulfurization technology, then it will have a huge demonstration effect on other desulfurization technology teaching. Therefore, teaching courseware of the limestone gypsum flue gas desulfurization, a Powerpoint with a new style, will be regarded as the other research target to show vividly those contents with system equipment and material flow process by the form of illustration. However, how do you combine two advantages between Authorware and Powerpoint? A new way, software embedding technology, will be used to bind them [24-25]. Finally, some optimal effects will be reached, which is to strengthen teaching process flexibility of the instructor and to facilitate understanding of the desulfurization process of the learner synchronously.

\section{FLUE GAS DESULFURIZATION SYSTEMS OF THE LIMESTONE-GYPSUM}

\section{A. Fundamental Principle of the Technical Process}

After raw flue gas crosses dust catcher and passes through gas-gas heat exchanger, raw flue gas with lower temperature and smaller dust enters into absorbing tower. Then the flue gas and limestone slurry added complete 
gas-liquid contact and sulfur dioxide in them will be absorbed efficiently. Afterwards, clean flue gas will flow through reheating side of gas-gas heat exchanger and be discharged from a chimney. The slurry absorbed will be used circularly. When the gypsum in the slurry reaches a certain degree of saturation, it is discharged into the gypsum preparation system, where gypsum is prepared as a by-product. The main reactions are written by formulas (2-1), (2-2), (2-3) and (2-4):

$$
\begin{aligned}
& \mathrm{SO}_{2}+\mathrm{H}_{2} \mathrm{O}=\mathrm{H}_{2} \mathrm{SO}_{3} \\
& \mathrm{H}^{+}+\mathrm{HSO}_{3}^{-}=2 \mathrm{H}^{+}+\mathrm{SO}_{3}^{-} \\
& 2 \mathrm{HSO}_{3}^{-}+\mathrm{O}_{2}=2 \mathrm{HSO}_{4}^{-}=2 \mathrm{SO}_{4}{ }^{2-}+2 \mathrm{H}^{+} \\
& \mathrm{Ca}^{2+}+\mathrm{SO}_{4}{ }^{2-}+\mathrm{H}_{2} \mathrm{O}=\mathrm{CaSO}_{4} \cdot 2 \mathrm{H}_{2} \mathrm{O}
\end{aligned}
$$

\section{B. Technological Process and System}

The wet limestone - gypsum flue gas desulfurization consists of three subsystems, which are subsystem of flue gas treatment and sulfur dioxide absorption, subsystem of gypsum dehydration and subsystem of reaction agent preparation, respectively. Schematic diagram of the process flow chart is shown in Fig. 1. The wet flue gas desulfurization system of limestone gypsum is composed of the following structure:

1. Limestone preparation system with a feed bin of limestone powder, a limestone mill and a measuring station.

2. Absorbing tower with a washing cycle, a demister and an oxidation procedure.

3. Flue gas reheat system with a rotary gas-gas heat exchanger and clean flue gas emissions system with a chimney.

4. Desulfurization fan.

5. Gypsum dewatering devices with a hydraulic cyclone separator and a vacuum filter belt machine.

6. Gypsum storage devices.

7. Wastewater treatment systems.

In above these systems and equipment, sulfur dioxide absorption of flue gas, gypsum generation and wastewater treatment will be completed when a power production is running normally.

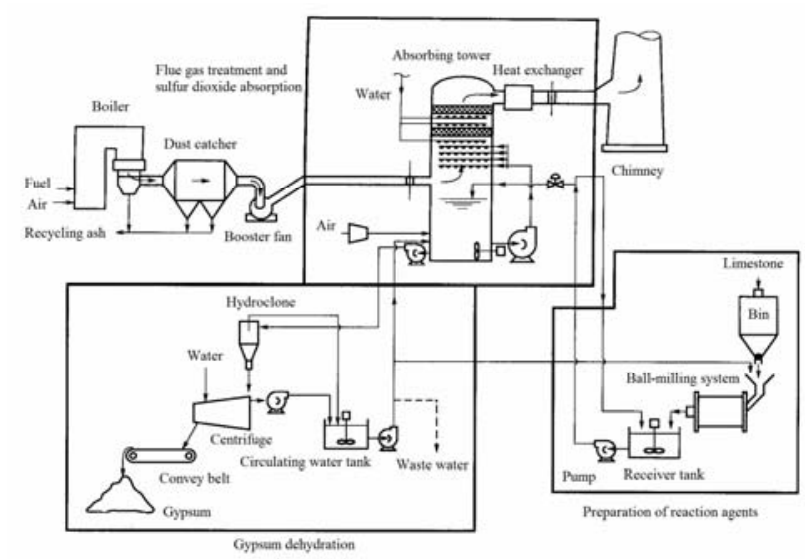

Figure 1. Schematic diagram of flue gas desulfurization system of limestone-gypsum

\section{COURSEWARE PRODUCTIONS}

\section{A. Multimedia Teaching Platform of Powerpoint}

\section{1) Courseware Frame of Powerpoint}

According to the typical Powerpoint design plan, set a home page and outline page. Necessary explanation such as a title of the paper, a name of the conference, the author will be given in home page. The frame structure of teaching contents will be elaborated in outline page. At the same time, set hyperlinks and buttons to enter the corresponding design page and make page conversion. Page specific styles are shown in Fig. 2 and Fig. 3.

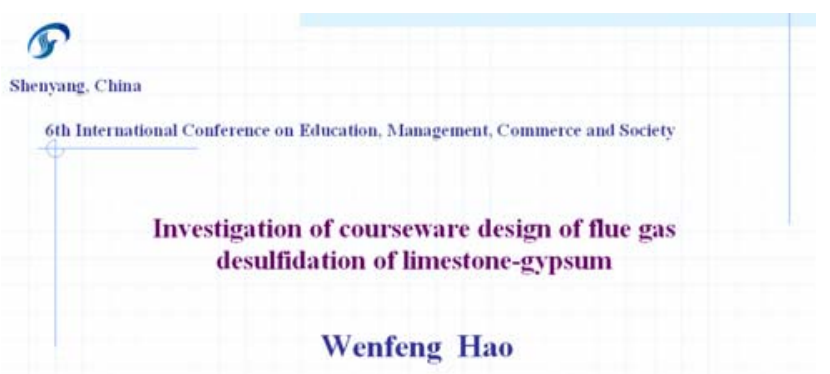

Shenyang Institute of Engineering

Figure 2. Home page of Powerpoint

\section{Outline}

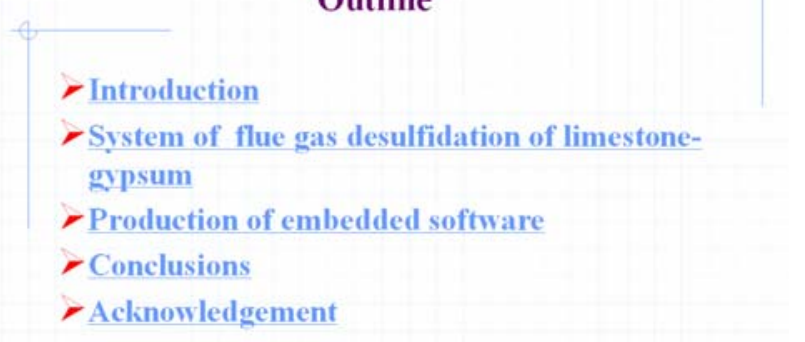

2015-10-10

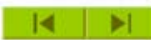

Figure 3. Initial interface design software

\section{2) Teaching Contents}

According to the outline order of this paper, the introduction, the limestone gypsum flue gas desulfurization system, the paper content production and conclusions are given. Further explanations of these parts are written as follows:

1. Background, existing problems and solutions of the existing desulfurization technology are analyzed in the introduction part. 
2. Working principle and technological process of the limestone gypsum flue gas desulfurization system are illustrated.

3. Form courseware teaching platform and use Authorware to produce an executable file of macromedia authorware 7 Runtime including static equipment, dynamic running of working conditions and test questions in courseware production part. And then embed the executable file to Powerpoint to make essential demonstration.

4. Summary for research results and suggestions will be given in conclusion part.

In view of the teaching content, the production methods of teaching courseware have been widely used. However, teaching courseware with human computer interaction has few reports. Thus, following sections will state a production of embedded software.

\section{B. Production of Embedded Authorware Executable File}

In order to make beginners of power engineering understand flue gas desulfurization process of thermal power plant in a relatively short period and expand the computer application software application in education and teaching, modular design function of Authorware will be used to demonstrate clearly the limestone gypsum flue gas desulfurization technology of thermal power plant and related basic knowledge under the static and dynamic form. The design framework is shown in Fig. 4, which consists of recognition system, the system run show and theory test.

From Fig. 4 we can understand that fundamental icons of Authorware such as display icon, interactive icon, frame icon, knowledge object icon and group icon, and the characteristics and integrated use of those icons can complete the framework design of the system.

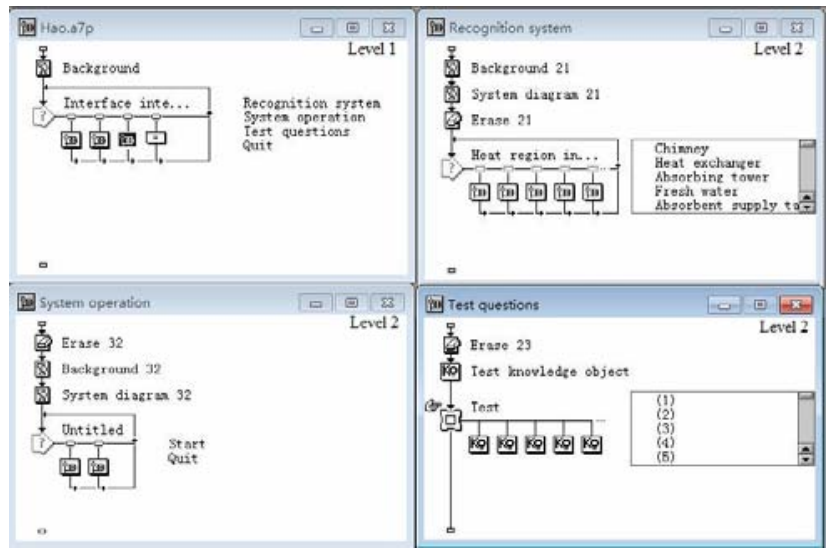

Figure 4. Software design framework

\section{1) Static demo}

First of all, drag a display icon to design interface and adjust the attributes and specific functions, create and display an interface as shown in Fig.5. Then, using inserting object function of displaying icon of Authorware, the system diagram drawn by Autocad is imported into the design recognition system, as shown in Fig.6.

Second, make static cognition system. Analyze coalfired power plant combustion system, limestone gypsum flue gas desulfurization, equipment, process in this part and know the entire equipment name and their respective roles then make "static cognition system". This part mainly use thermal interaction icon, drags a group icon and display icon into flow line, the name, equipment structure and function, and set a hot region. Regional scope is fixed on the device, and set a click. When click is implemented the equipment instruction including structure and function will be shown. The lectures or software users can understand and learn the system by the static demonstration of the devices and equipments' functions. The design levels of the recognition are shown in Fig.7-a. From the picture of Fig.7-b, we can see that equipment and its functions can be stated distinctly. Not only it is easy to interpret equipment and its function for the lecture of lessons, but also it is convenient to comprehend the equipment and its functions in the flue gas desulfurization process.

In addition, button operation is applied into design and operation of the system. Use a button to control the flow of the material in different parts to facilitate the users of understanding of the software of the courseware and intuitive understanding of the process. If you press the operation, the flow of material such as flue gas current, calcium current, air current can be clearly indicated according to the direction of flow.

\section{2) Dynamic demo}

Prior to schematic diagram generation for a limestone gypsum flue gas desulfurization, the combustion system of thermal power plants, combustion system, steam and water system and electrical system should be fully understood and master system in material, energy conversion and transfer process. Limestone gypsum flue gas desulfurization demonstration includes flue gas system, discharge system of ammonia, liquid ammonia evaporation supply and reaction system, the demonstration interface is shown in Fig. 8.

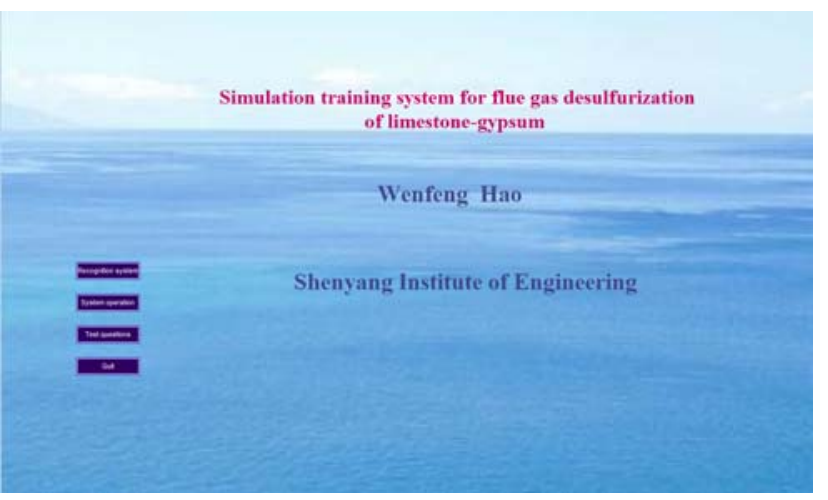

Figure 5 Initial interface design of the static demo 


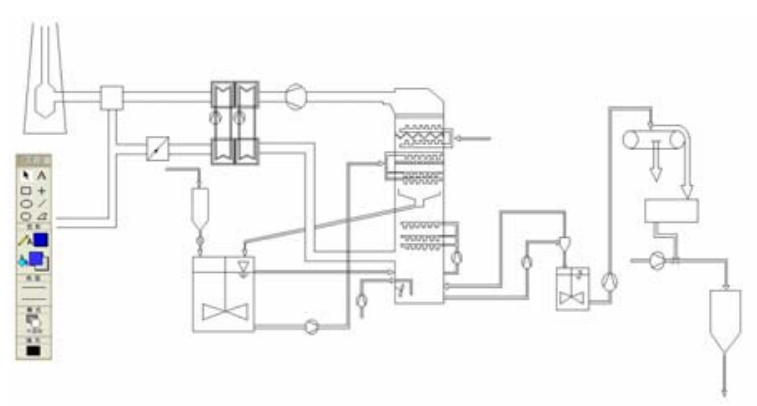

Figure 6 Import of system diagram

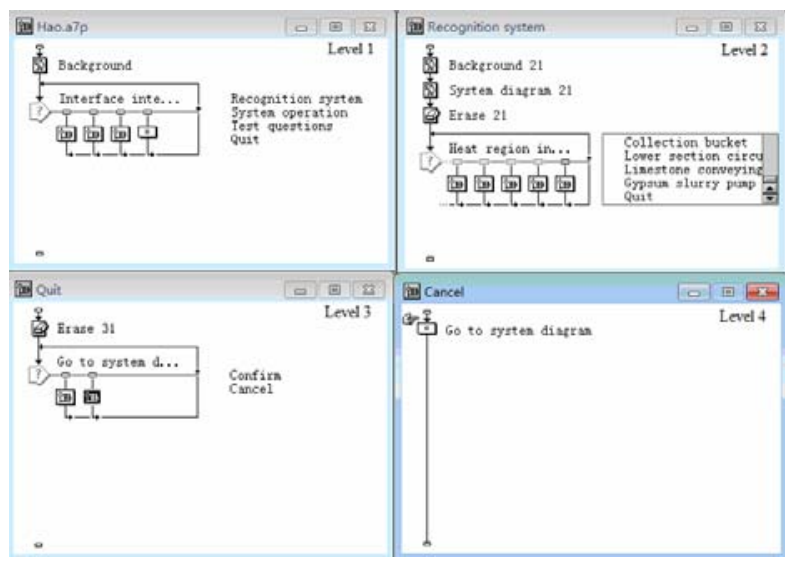

Figure 7-a. Schematic diagram of "Cognition system" structure

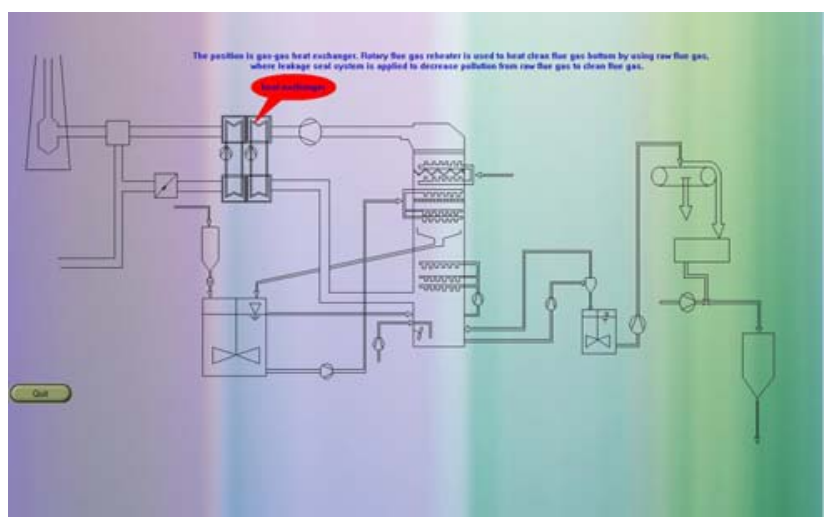

Figure 7-b. Schematic diagram of static demonstration for the devices

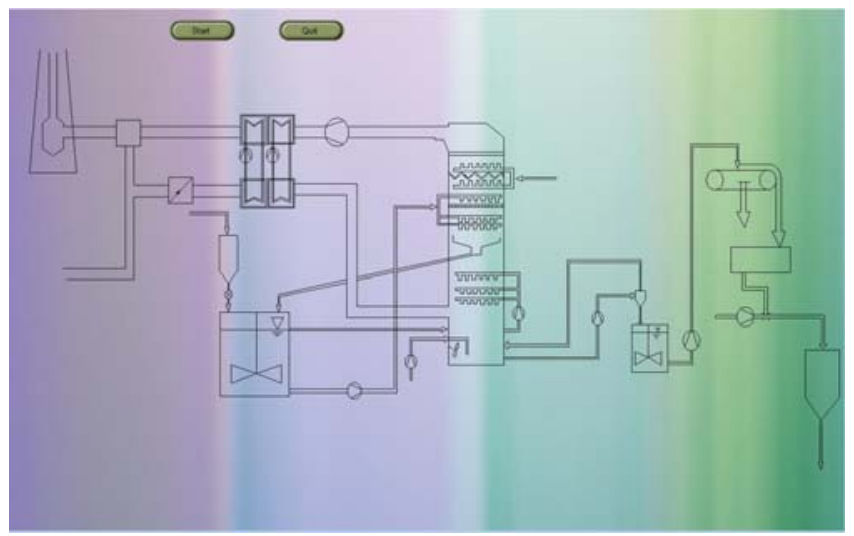

Figure 8. Operation interface of limestone gypsum flue gas desulfurization

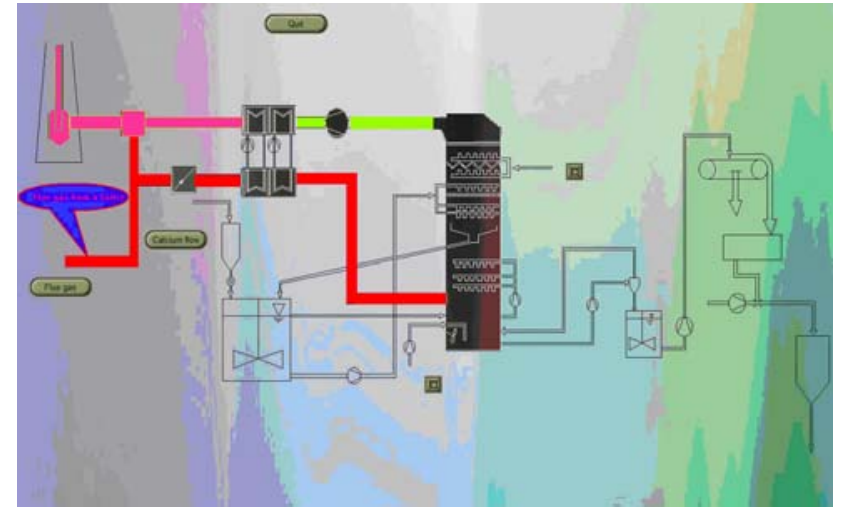

Figure 9-a. Flue gas flow chart

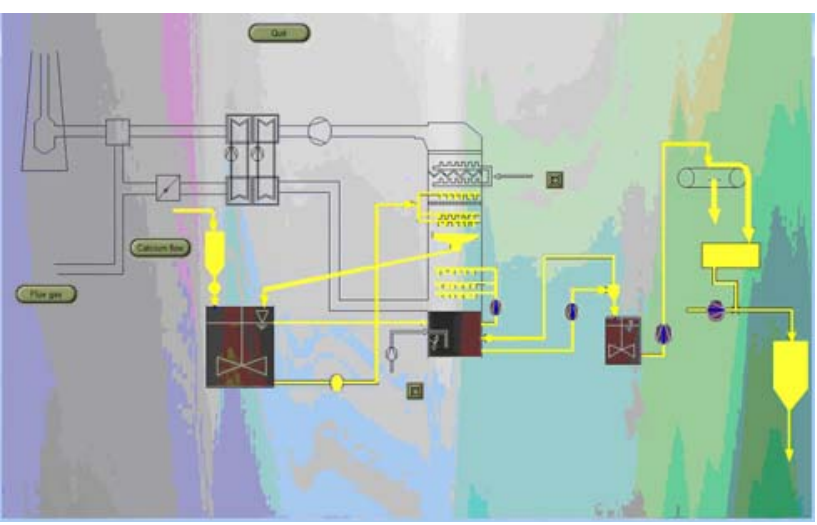

Figure 9-b. Calcium current flow chart

For the production of dynamic demonstration of the running system, show of flue gas flow and calcium current as samples are used to reveal all kind of mass transfer processes in this paper. Colored coatings shown in Fig. 9-a indicate a flow direction of the flue gas, whose run process can show process control of raw flue gas and clean flue gas in the system when a power plant runs under a normal state. Yellow coatings shown in Fig. 9-b reveals trajectories of calcium current when the power plant runs. The process using Authorware production can be described as follows:

By using button interactive icon function button "start" and button "quit" are set up. Under the condition of the start button, through different levels of "group" icons the equipment and parts of different substances flow in terms of the order will be arranged in the upper and lower levels of the "group" icons, also special effects of the coating for each schematic diagram are set. After the program runs different substance will come out in an order with different special effects, and ultimately man feels that a substance is moving in an equipments and pipelines. When button "quit" is pressed, when operation system will return to an initial interface as shown in Fig. 5. The production process are shown in Fig. 10-a and Fig. 10-b. The humancomputer interaction is beneficial to understand and grasp mass transfer, heat transfer, momentum transfer 
and relevant to chemical reaction for the limestone gypsum flue gas desulfurization processes whether lectures or learners.

\section{3) Production of test questions}

In order to increase to understand and grasp the application of limestone gypsum flue gas desulfurization in thermal power plant, functions of navigation and knowledge object are applied to make test questions. During the production of the test questions, a navigation icon and some knowledge object icons are firstly dragged into test questions framework. Then selection response including page size, background, types and number are done according to page hint. 30 singel-choices, production procedures and effects example are shown in Fig. 11-a and Fig. 11-b. Through the study of the production process and the knowledge learn of flue gas desulfurization of thermal power plant, instructors can provide a platform for the consolidation of knowledge of flue gas desulfurization during teaching, while the software users will have a deep understanding of the software itself and the fundamental knowledge of the environmental protection of thermal power plant.

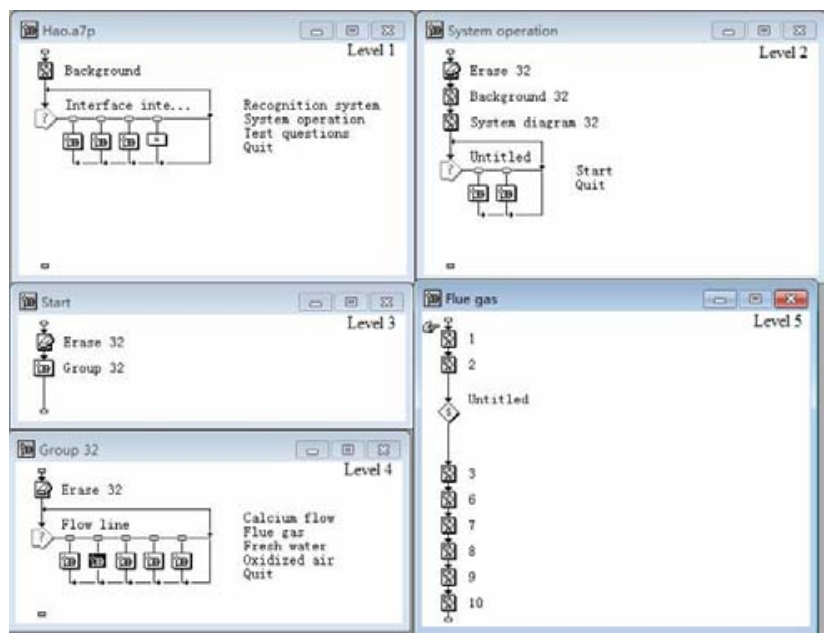

Figure 10-a. Production chart of flue gas flow

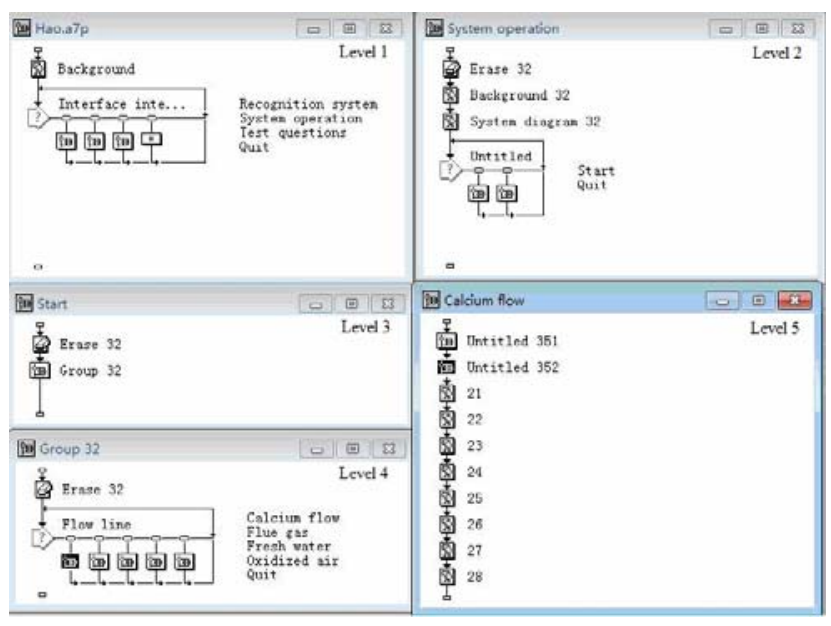

Figure 10-b. Production chart of calcium current

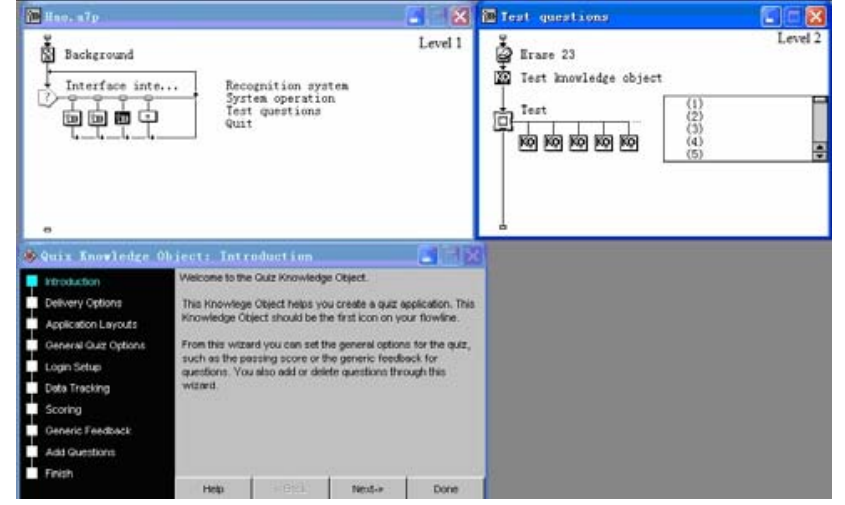

Figure 11-a Production process of test questions

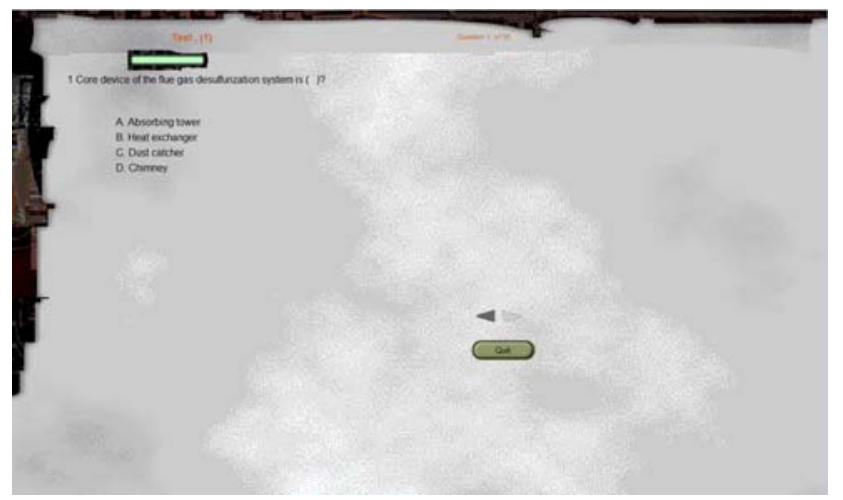

Figure 11-b Run schematic diagram of test questions

\section{4) Formation of an executable file}

Software with the static demonstration, the dynamic demonstration and the test question is packed to become an executable file of macromedia authorware 7 Runtime, which can be embedded to Powerpoint courseware in order to do course teaching of human-computer interaction by lectures.

\section{CONCLUSIONS}

After instructor completes teaching courseware aforementioned it will be applied to lesson teaching. From courseware production to normal teaching for the limestone gypsum flue gas desulfurization process, following conclusions can be drawn.

1.Process flowchart and some fundamental knowledge of thermal power plant can be demonstrated clearly under the static state and dynamic state by the modular design function of Authorware.

2. Test questions can provide a platform strengthening understanding and prolongation of basic knowledge of the environmental protection whether for the knowledge transfer of lectures or for the knowledge absorption of learners.

3.Powerpoint teaching courseware with an executed file of Authorware has vivid characteristic compared to general courseware since human computer interaction and animation are introduced to lessons teaching, which will have stronger representing ability and will gain better teaching effects than before. 
4. Lectures will be easier to express the equipments and technical process and will be more convenient to teach mass transfer, heat transfer, momentum transfer and chemical reaction for all kinds of substances in the limestone gypsum flue gas desulfurization system.

5. Learners can not only have a more profound understanding of the material, energy conversion and transfer process of thermal power plant, but also they can master the method of process modular design through their own continuous learning comparing to conventional teaching when they attend a lecture using this courseware.

\section{ACKNOWLEDGMENT}

The financial support from the Natural Science Foundation of Liaoning Province (No. 2013020150) and the Program for Liaoning Excellent Talents in University (No.LJQ2011134) in China are gratefully acknowledged.

\section{REFERENCES}

[1] P. Córdoba , "Status of Flue Gas Desulphurisation (FGD) systems from coal-fired power plants: Overview of the physicchemical control processes of wet limestone FGDs,” Fuel, Vol. 144, Mar., 2015, pp. 274-286, doi: 10.1016/j.fuel.2014.12.065

[2] H. Zhang,B. Zhang, J. Bi, "More efforts, more benefits: Air pollutant control of coal-fired power plants in China," Energy, Vol. 80, Feb., 2015, pp. 1-9, doi: 10.1016/j.energy.2014.11.029

[3] Z. Wang, L. Pan, Y. Li,D. Zhang, J. Ma, S. Feng, W. Xu, X. Wang, "Assessment of air quality benefits from the national pollution control policy of thermal power plants in China: A numerical simulation,” Atmospheric Environment. Vol. 106, Apr., 2015, pp. 288-304, doi: 10.1016/j.atmosenv.2015.01.022

[4] X.Luo,J. Hu,J. Zhao,B. Zhang,Y. Chen, S. Mo, "Multi-objective optimization for the design and synthesis of utility systems with emission abatement technology concerns," Applied Energy, Vol. 136, Dec., 2014, pp. 1110-1131, doi: 10.1016/j.apenergy. 2014.06.076

[5] H.Wang, H.Ding, G.Yao, Y.Zhang, C.Zheng, X.Gao,Z.Luo,K.Cen, "Experimental study on $\mathrm{SO}_{2}$ absorption rate enhanced by additive in limestone-gypsum WFGD process,” Journal of Zhejiang University (Engineering Science), Vol. 48, Jan., 2014, pp. 50-55, doi: 10.3785/j.issn.1008-973X.2014.01.008

[6] J. A. Licata, R. D'Alessandro, T. Clark, "The use of NPV calculations to evaluate the selection of FGD technologies," Air and Waste Management Association - Power Plant Air Pollutant Control "MEGA" Symposium 2012, Vol. 2, 2012, pp. 1250-1262

[7] D. G. Fenske, J. P. Williams, A.C. Palmberg, J. Jenkins, "New life for a dual loop wet FGD system," Air and Waste Management Association - Power Plant Air Pollutant Control "MEGA" Symposium 2012, Vol. 2, 2012, pp. 1013-1030

[8] D. Yang, "Application status and economic analysis of active coke flue gas desulfurization technology," Advanced Materials Research,Vol.610-613,2013,pp.1463-1468, doi:10.4028/www. scientific.net/AMR.610-613.1463

[9] F. Zhu, J.Gao, X.Chen, M. Tong, Y. Zhou, J. Lu, "Hydrolysis of Urea for Ammonia-Based Wet Flue Gas Desulfurization,” Industrial and Engineering Chemistry Research, Vol. 54, Aug., 2015, pp. 9072-9080, doi:10.1021/acs.iecr.5b02041

[10] Y.Jia,Q. Zhong, X. Fan, X. Wang, "Kinetics of oxidation of total sulfite in the ammonia-based wet flue gas desulfurization process,"
Chemical Engineering Journal, Vol. 164, Oct. 2010, pp. 132-138, doi:10.1016/j.cej. 2010.08.041

[11] X.Wang, Z.Li, L.Lei, "Model study of sulfite oxidation in seawater flue gas desulfurization by cylindrical wetted-wall corona-streamer discharge," Chemical Engineering Science, Vol. 97, Jun., 2013, pp. 7-15, doi: 0.1016/j.ces. 2013.04. 011

[12] Wang J., Zhang S., Jing R., Li W., "Seawater flue gas desulfurization with parallel flow tray for power plant,” Asia-Pacific Power and Energy Engineering Conference, APPEEC, 2012, Article number 6306950, doi: 10.1109/APPEEC.2012.6306950

[13] X.Su,L.Zhang,Y.Xiao,Sun M.,X.Gao,J.Su,“Evaluation of a flue gas cleaning system of a circulating fluidized bed incineration power plant by the analysis of pollutant emissions,” Powder Technology, Vol. 286, Dec., 2015, pp. 9-15, doi:10.1016/j.powtec.2015.07.038

[14] J. E.Anthony, “Oxyfuel CFBC:Status and anticipated development,”Greenhouse Gases: Science and Technology, Vol. 3, Apr., 2013, pp. 116-123, doi: 10.1002/ghg.1324

[15] D. Liu, C. Zhang, J. Xia, G. Chen, "Feasibility study of an infurnace calcium spraying desulfurization auxiliary system for a large-capacity boiler,” Journal of Engineering for Thermal Energy and Power, Vol. 27, Jul., 2012, pp. 472-477

[16] J.Yao, "A new kind of united treatment technology of "Three Wastes" from paper mill and flue gas from boiler," Advanced Materials Research, Vol. 197-198, 2011, pp. 861-864, doi: 10.4028/www.scientific.net/AMR.197-198.861

[17] P.A.Costa,P.L.Reis,J.M.Loureiro,"Hybrid user centered development methodology: An application to educational software development," Lecture Notes in Computer Science, Vol. 8699, 2014, pp. 243-253, doi: 10.1007/978-3-319-13296-9_27

[18] T.Li, W. Gu , C. Li , "Intelligent realization of teaching courseware framework system,” Applied Mechanics and Materials, Vol. 519520, 2014, pp. 1661-1664,doi: 10.4028/www. scientific. net/AMM.519-520.1661

[19] T. Rajula Shanthy, and R. Thiagarajan, "Interactive multimedia instruction versus traditional training programmes: Analysis of their effectiveness and perception,” Journal of Agricultural Education and Extension. Vol. 17, Oct. 2011, pp. 459-472, doi: 10.1080/1389224 X.2011.596708

[20] J. Simon, "PowerPoint and Concept Maps: A Great Double Act," Accounting Education, Vol. 24, Mar. 2015, pp. 146-151, doi: $10.1080 / 09639284.2015 .1036583$

[21] J.Li, "Based on authorware courseware design," Advanced Materials Research.vol.971-973, 2014, pp. 2744-2747, doi: 10.402 8/www.scientific.net/AMR.971-973.2744

[22] Y. Pisan, and C.T. Tan."Use of student-designed authorware for emediated science and technology learning," ICCSE 2012Proceedings of 2012 7th International Conference on Computer Science and Education. 2012, Article number 6295377, pp.16331637, doi: 10.1109/ ICCSE.2012.6295377

[23] W.F. Hao, "Investigation of authorware application for power production teaching,” Advances in Intelligent System Research, Vol.117, Aug., 2015, pp.1593-1597

[24] D.D. Wei, L.X. Qiu, "Research on key technologies of multimedia courseware operation based on authorware," Applied Mechanics and Materials. 2014(443):571-575 vol. 443, 2014, pp. 571-575, doi: 10.4028/www.scientific.net/AMM.443.571

[25] C. H. Powell , J. B. Dugan , "BYOE: Student designed advanced laboratories for embedded computing concepts, hardware, and design,” ASEE Annual Conference and Exposition, Conference Proceedings, Vol. 122nd ASEE Annual Conference and Exposition: Making Value for Society, Issue 122nd ASEE Annual Conference and Exposition: Making Value for Society, June, 2015 